\title{
APPLICATION OF PHYSICALLY-BASED EROSION 3D MODEL IN SMALL CATCHMENT
}

\section{Zuzana Németová ${ }^{1}$}

\section{David Honek ${ }^{2}$}

\section{Tamara Látková ${ }^{1}$}

${ }^{1}$ Slovak University of Technology in Bratislava, Slovakia

${ }^{2}$ Masaryk University, Czech Republic

\begin{abstract}
The scope of this study is the application of new approach for estimation of potential soil erosion in the Slovakia using a physically-based erosion model Erosion 3D for modelling potential erosion in the Myjava River basin. Erosion 3D is a physically-based computer model for predicting soil erosion by water on agricultural land (Schmidt, 1996). The model is predominantly based on physical principles and it simulates surface runoff, erosion, deposition and the detachment of soil particles for single events, and provides good tool for simulate and quantify soil erosion, but has not been established in Slovakian basins yet. The soil system of Erosion 3D is based on the fourth edition of the Bodenkundliche Kartieranleitung („KA 4“, AG Boden, 1994). Because of different soil types it was required in the first step to create an overplot of KA 4 textural system with the USDA textural system used in Slovakia. The model requires three input parameter - relief, precipitation and soil parameters. The first two parameters are easy to obtain but soil input parameters are more complicated mainly for different areas where the model was calibrated and validated. In this study we focused to creation of the soil input data sets for Slovak condition including establishment of Parameter catalog for every soil input parameters. The catalog has been configured based on overplotted textural triangle. The Erosion 3D model was applied to a small catchment Tura Luka situated in the Myjava Hill Land which is known for its quick runoff response and related muddy floods. Four scenarios of initial moisture parameter, which is considered as the most sensitive soil input parameter, were applied. Simulations were done for 100year design rainfall of 60 minutes duration. The results of potential erosion are wellcapable to point to the spatial and temporal variability of the rainfall event with the wide range of the values.
\end{abstract}

Keywords: Erosion, 3D model, textural system, event based model.

\section{INTRODUCTION}

Soil erosion as the process of natural character is strongly accelerated by human activity (Stankoviansky, 2003). Erosion is a natural and diffuse process which occurs at relatively low and widely varying rates from year to year and from location to location (Kenderessy, 2012). It cannot be completely eliminated by any measures or interventions. The only thing that is possible and necessary to do is to reduce its intensity and impact (Antal et al., 2013). Practical measurement of soil erosion is quite difficult and there are many problems associated with monitoring and surveying processes of erosion. This is the reason why the modelling of erosion and erosion- 
accumulation processes can be helpful to estimate the intensity of processes at different scales (Vysloužilová, Kliment, 2012).

Modelling of water erosion can be conducted by empirical or physically-based models. The first one (empirical models) are the simplest of all three model types and they are based primarily on the analysis of observations data (Wheater, et al., 1993). Universal soil loss equation (USLE) is widely used and it is typical represent of empirical models. Second group (physically-based models) require specific parameters (Schindewolf, 2012), where erosion processes are described by difference equations. (Pandey, 2016). Physical model can overcome many defects of empirical models because of the use of parameters having physical interpretation (Abbot, 1986).

In this article, the physically-based erosion model Erosion-3D is used for calculations. The model has been developed since 1995 by Michael von Werner at the Department of Geography in Berlin (Werner, 2006). The model is able to predict the amounts of soil erosion and deposition from both a single extreme rainstorm and a series of numerous rainfall events which occur within a longer period such as one year or decade (Michael, et al. 1996). Erosion-3D simulates surface runoff, erosion, deposition, volume and concentration of the eroded sediment for single erosion events as a function of time and space (Weigert, et al., 2003).

Many researches have been concerning at the Myjava Hill Land, describing the erosion processes and their consequences in the land scape (e.g. Bučko, 1972; Gajdová, 1999; Stankoviansky et al., 2008). These studies took advantage of empirical models based on USLE equation, because it is very simple and often-used method for calculation of potential soil water erosion across the world. However, empirical models mainly use the topographic information together with amount of precipitation to model soil processes. The physical-based models are designed to calculate soil erosion through mathematical and physical equation, e.g. hydrological conductivity, so that the models should be able to calculate the real processes more accurate (Bhuyan et al., 2002; Nearing et al., 2005).

The main objective of this study is to present the new approach for modelling of the erosion processes in the small Slovak catchments. For this purpose, the small catchment in the middle of Myjava Hill Land was chosen, and the calculations were done thanks to physically-based erosion model called Erosion-3D.

\section{MATERIAL AND METHODS}

\subsection{Study site}

The study area is situated in western Slovakia in the middle of the Myjava Hill land, near to the city of Myjava - Turá Lúka district (Fig. 1). The elevation ranges from 298 $\mathrm{m}$ to $391 \mathrm{~m}$ above the mean sea level. The study area is composed by small watersheds, draining approximately $1 \mathrm{~km}^{2}$ of the agricultural land. The permanent gully (length about $300 \mathrm{~m}$ ) is located in the middle of the study area (the minimum altitude is 300.5 meters above sea level; the maximum altitude is 328.8 meters above sea level). The climate of the area is continental, warm and moderately humid, with mild winter and warm summer. The mean annual precipitation is between 650 and $700 \mathrm{~mm}$ and the mean annual temperature is about $8.8^{\circ} \mathrm{C}$. 


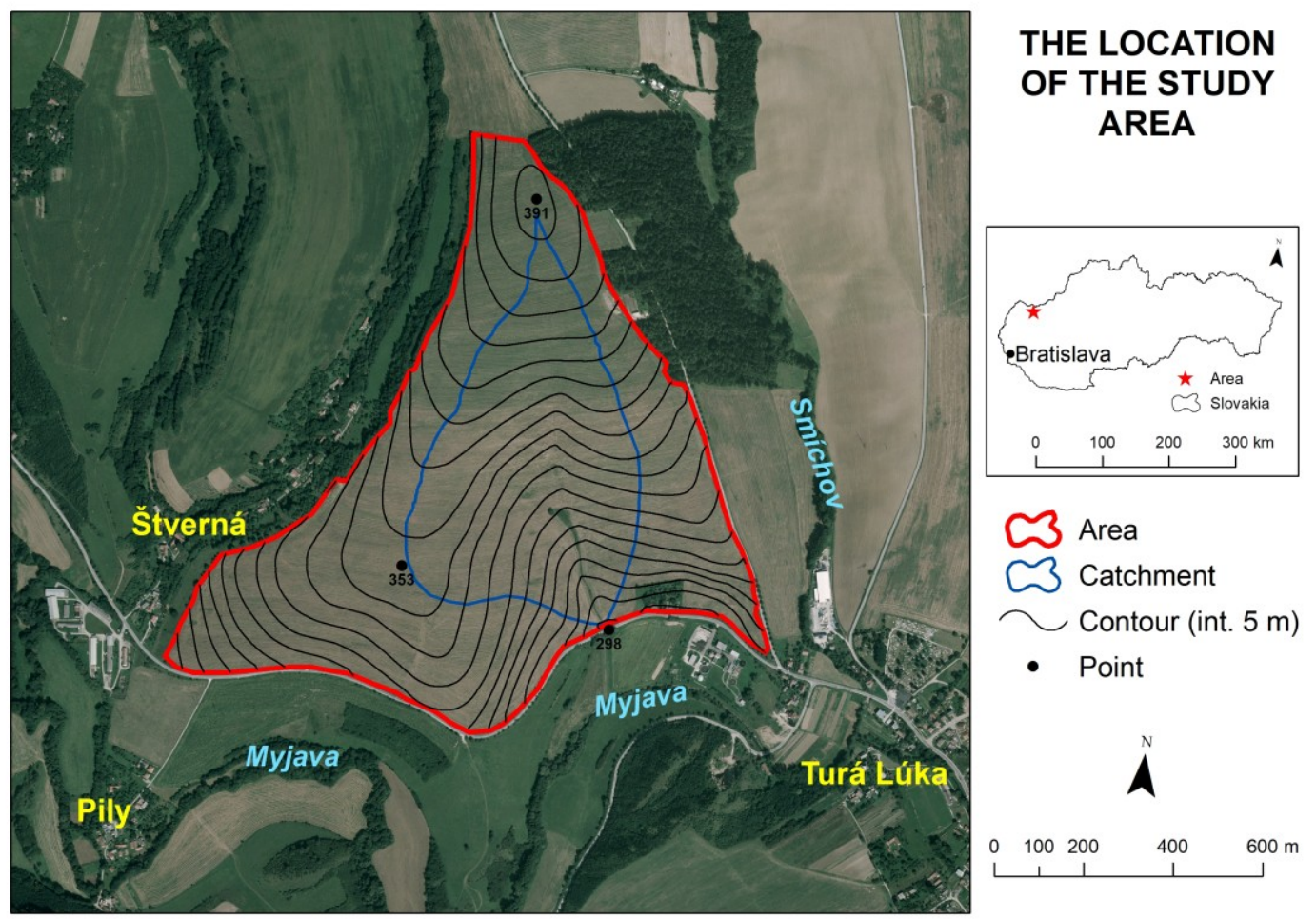

Figure 1: The location of the research area in Turá Lúka.

\subsection{Erosion-3D model - input parameters}

For modelling in the model is needed three input parameters; relief (DEM in a form of a square grid), precipitation (duration and intensity) and soil parameters (bulk density, organic carbon content, erodibility, Manning's n, cover, grain size distribution, skin factor). The most sensitive soil input parameter of the model represent initial soil moisture but also it is one the most temporal (during the day, before or after the rainfall event) and spatial (different position on a slope) variable parameter. This is the reason why creating scenarios of initial soil moisture can be solution. The range of the parameter should be based on real terrain measurement data. In our study the range of the initial moisture is from $10 \%$ to $45 \%$ based on the real field measurements in the catchment Tura Luka. The calculations were done for 8 scenarios of initial moisture parameters for three types of land cover: fallow, winter wheat and corn for silage for one hour single event.

In the study DEM with spatial resolution 10x10 m and 100 years design rainfall with intensity $31 \mathrm{~mm} / \mathrm{h}$ were applied. Other soil input parameters were taken from parameter catalogue (Michael, 1996). Because the catalogue was calibration and validation in the Germany, it was required to create an overlay of KA 4 textural system (used in the model) with the USDA textural system (used in Slovakia) (Fig. 2). Based on the triangle the catalogue of parameters has been configured for USDA soil system. Four scenarios of initial moisture in the range of 10-40 percent was created. 


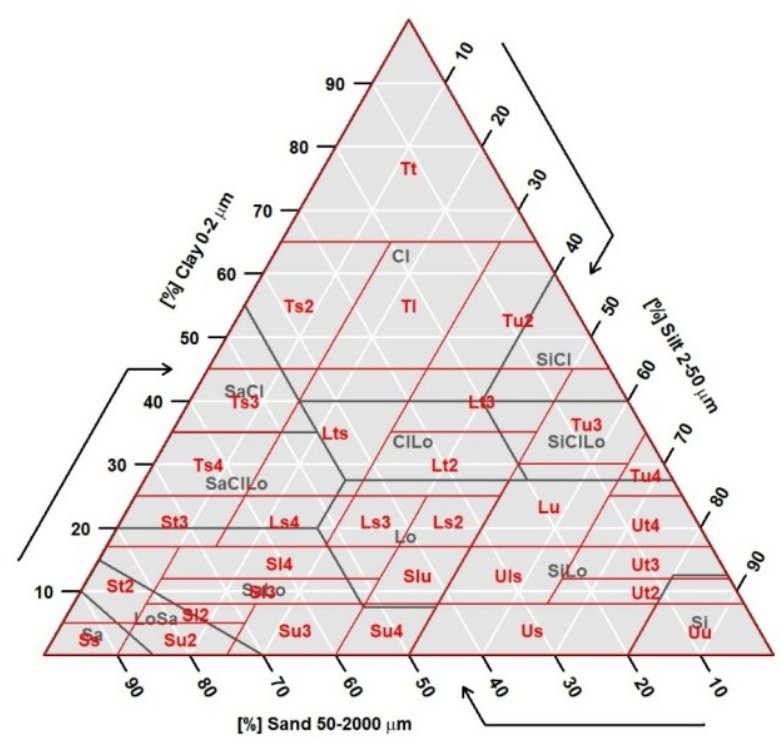

Figure 2. Overplotted triangle USDA and KA 4.

\section{RESULTS AND DISCUSSION}

The potential soil water erosion was calculated by Erosion-3D model in a small catchment in the Myjava Hill Land, and the model was successfully calibrated for Slovak soil conditions. Our results show the strong interaction between soil condition and potential soil water erosion, corresponding also to relief and precipitation. Werner (2004) mentioned that the model is very sensitive to initial moisture content, which was confirmed by our results.

Intensity of erosion is very high in the middle of the catchment, which is caused by the high value of the runoff in this part. The main stream and also the small gully are located in this part of the catchment. Obviously, the intensity of erosion relates to graduated slope steepness. The results are demonstrated for fallow and winter wheat on Figure 3. It is known, that the variability of the initial soil moisture is crucial among the field conditions. The graduated moisture influence the surface runoff, which means the higher initial moisture cause bigger surface runoff and also soil erosion. The first moisture scenario is without values, because the entire amount of rainfall was saturated (for all land covers). The biggest intensity of soil erosion was calculated for fallow land cover, ranging from 131.92 to 367.39 tons per hectare for three moisture scenarios (Tab.1). This intensity is much higher than the intensity calculated for the winter wheat land cover (ranging from 3.50 to 6.96 tons per hectare), which is logical because the winter wheat covers the surface and create a barrier for surface runoff. The similar trend

Table 1. Characteristics calculated for two kinds of land cover and four initial soil moisture scenarios.

\begin{tabular}{|c|c|c|c|c|}
\hline \multirow{2}{*}{$\begin{array}{l}\text { Moisture } \\
\text { scenario }\end{array}$} & \multicolumn{2}{|c|}{ Fallow } & \multicolumn{2}{c|}{ Winter wheat } \\
\cline { 2 - 5 } & $\begin{array}{c}\text { Erosion } \\
\text { (t/ha) }\end{array}$ & $\begin{array}{c}\text { Sediment } \\
\text { conc. } \mathbf{( k g / \mathbf { m } ^ { 3 }} \text { ) }\end{array}$ & $\begin{array}{c}\text { Erosion } \\
\text { (t/ha) }\end{array}$ & $\begin{array}{c}\text { Sediment } \\
\text { conc. } \mathbf{( k g / \mathbf { m } ^ { \mathbf { 3 } } \text { ) }}\end{array}$ \\
\hline $\mathbf{1 ( \mathbf { 1 0 } \% )}$ & 0.00 & 0.00 & 0.00 & 0.00 \\
\hline $\mathbf{3 ( 2 0 \% )}$ & 131.92 & 107.76 & 3.50 & 1.84 \\
\hline $\mathbf{5 ( 3 0 \% )}$ & 283.13 & 126.44 & 5.79 & 2.19 \\
\hline $\mathbf{7 ( 4 0 \% )}$ & 367.39 & 135.33 & 6.96 & 2.35 \\
\hline
\end{tabular}



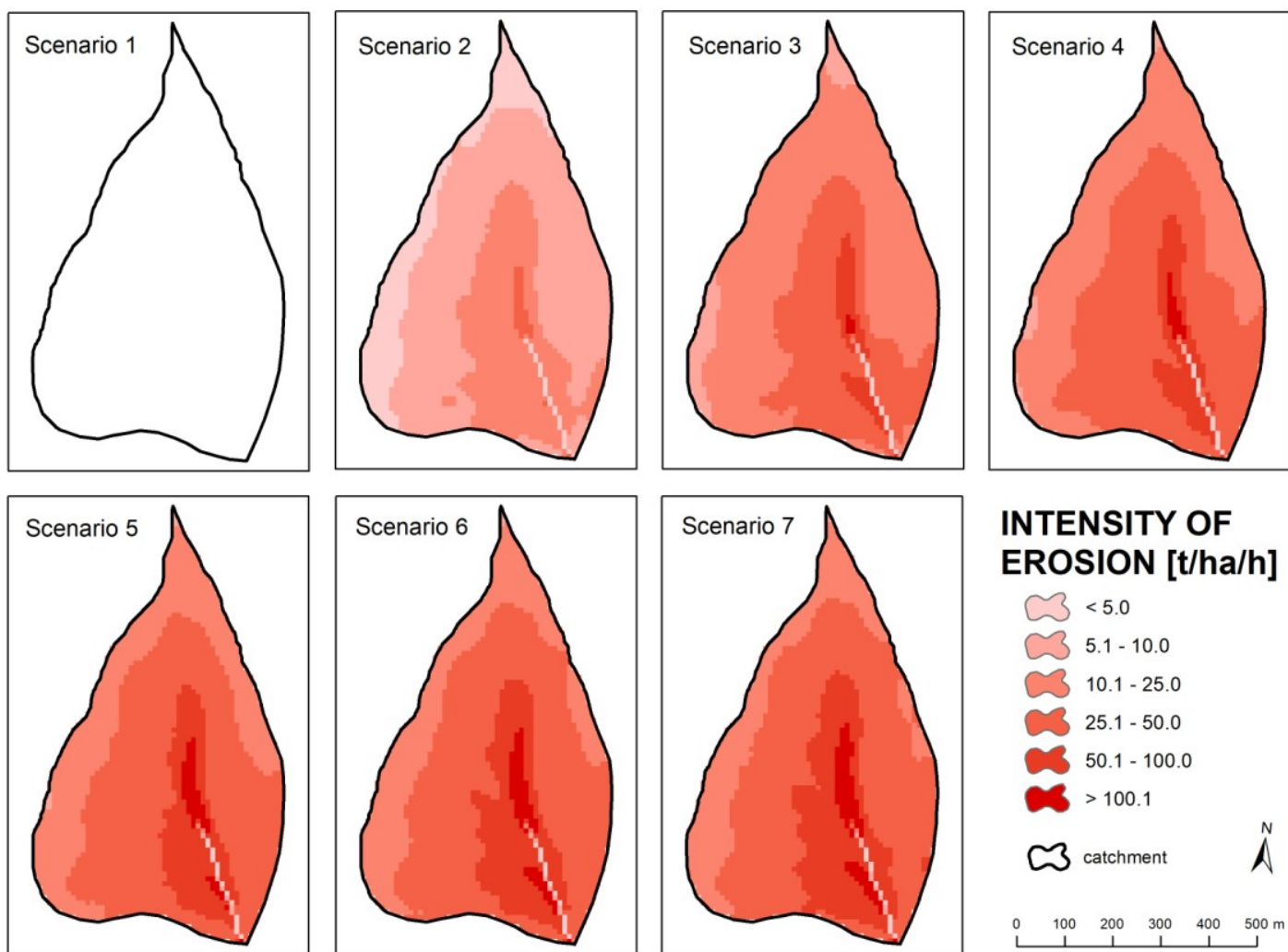

\section{INTENSITY OF EROSION [t/ha/h]}

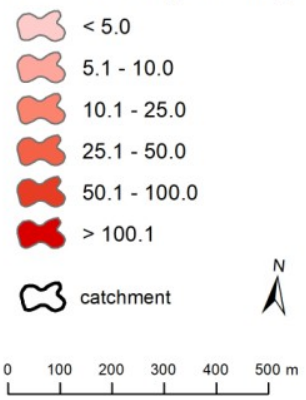

Figure 3. Intensity of potential soil water erosion in the research area.

can be seen in the value of sediment concentration. Finally, it is obvious that rising initial soil moisture cause higher amount of sediments and intensity of erosion too.

Considering the dependence between soil moisture and chosen model's outputs, the results show strong relationship between soil moisture and intensity of erosion (correlation coefficient $R>0.98$ ), significant with $\mathrm{p}<0.05$. The correlation between soil moisture and sediment concentration is a little bit lower $(R>0.86$, significant with $\mathrm{p}<0.05)$, but it is still high relationship. In the light of regression analyses calculated for both applied land covers, the mentioned high correlations were confirmed by polynomial function and correlation of determination on Figures 4 and 5.

In our opinion, the EROSION 3D model is very good tool for quantifying of soil erosion and other characteristics in small catchments, considering the variability of inputs data (mainly the soil data set). Most of these data were available as parameter estimates derived from the predefined parameter catalogue. However, for more accurate results it is better to use real measured data, mainly the initial soil moisture as the most real-variable soil characteristic.

\section{CONCLUSION}

Nowadays, a physically-based erosion models represent a good approach to predict and to quantify the soil loss in the wide spatial range. One of these model is Erosion-3D model which was used in this paper. The Erosion-3D model is good tool for calculation of potential soil water erosion, dealing with different physical-geographic conditions. 


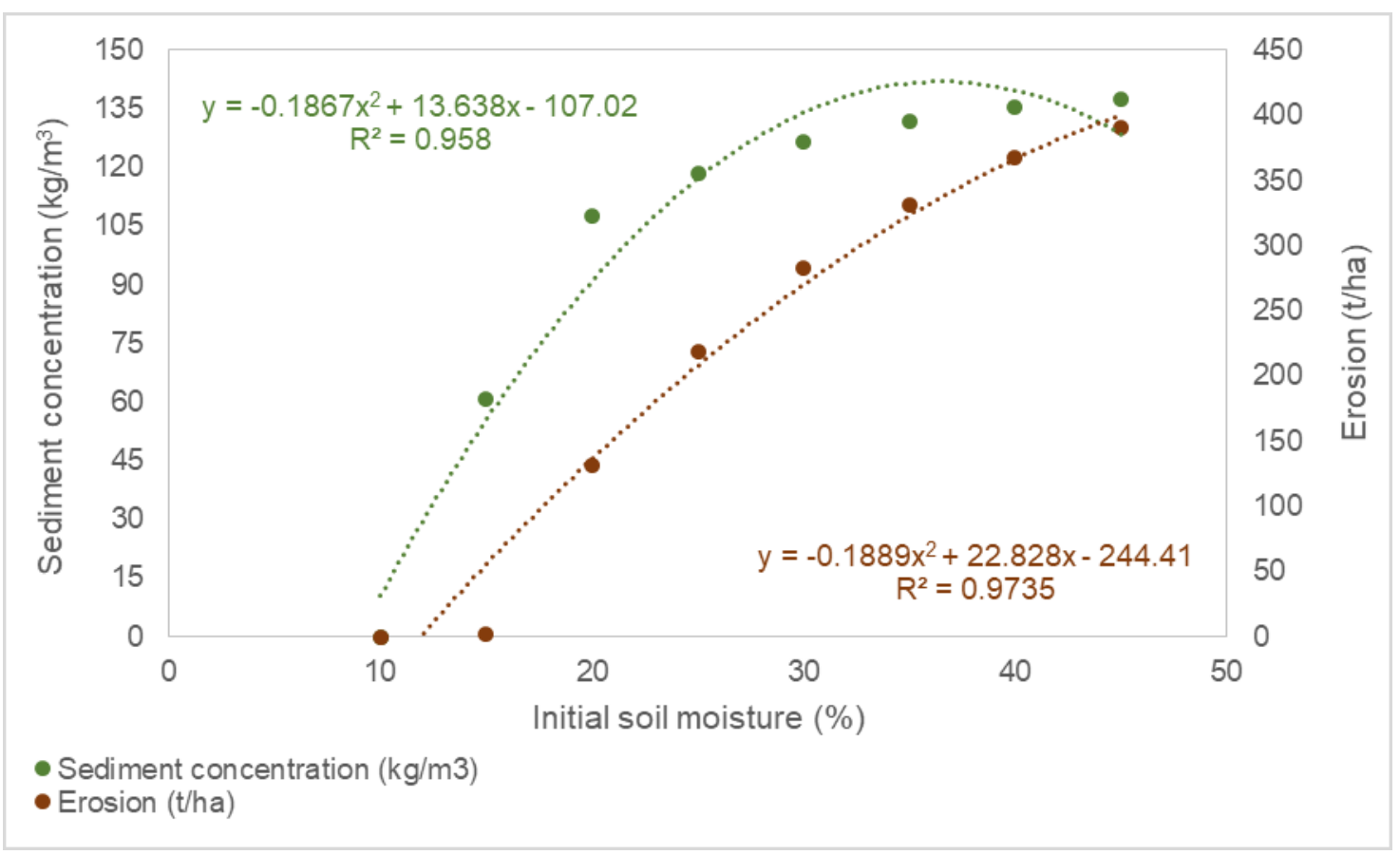

Figure 4. The regression analysis among initial soil moisture, soil erosion and sediment concentration. Example for fallow land cover.

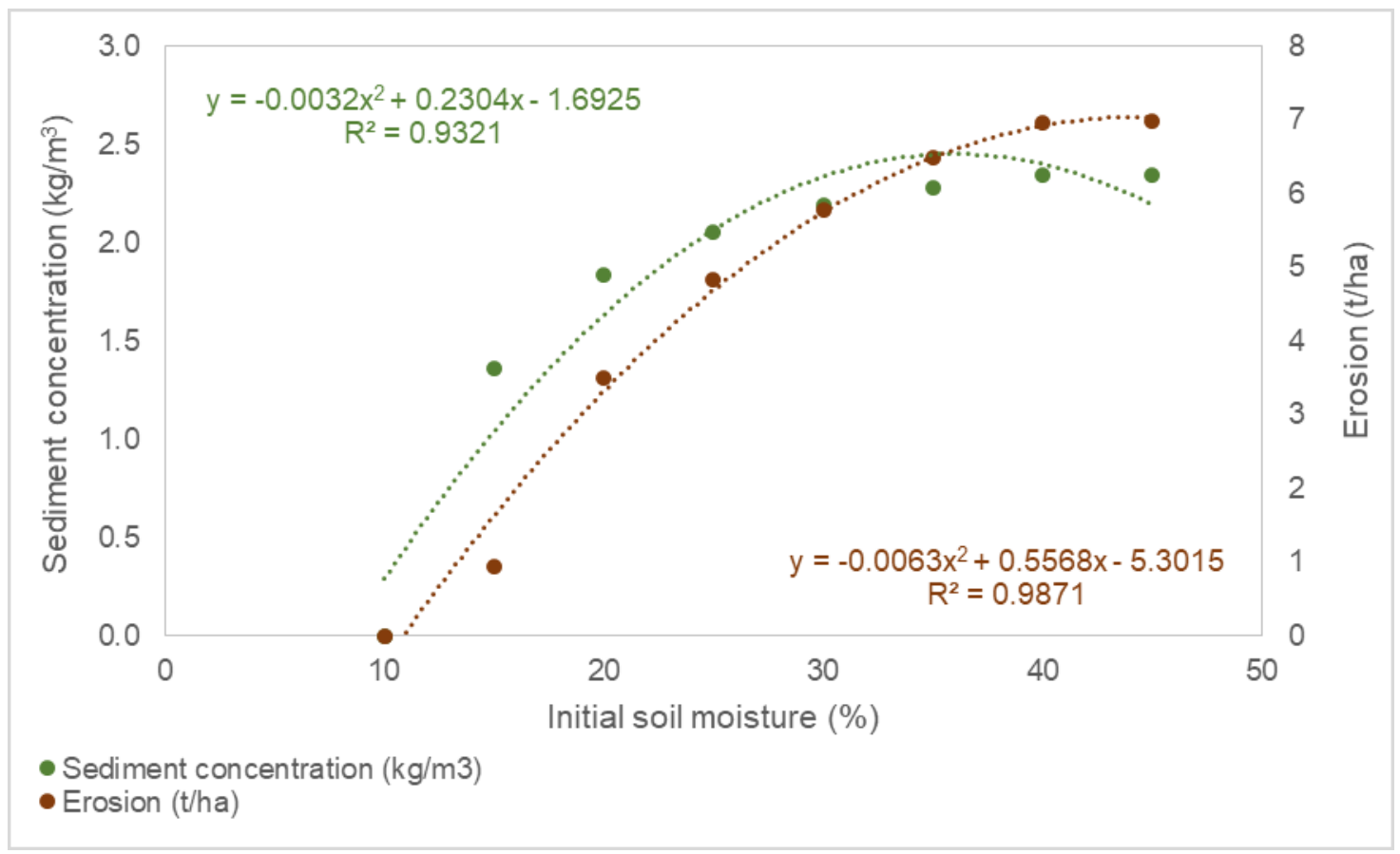

Figure 5. The regression analysis among initial soil moisture, soil erosion and sediment concentration. Example for winter wheat land cover.

However, the soil input data based on defined parameter catalogue doesn't reflect all real-measure soil conditions and differences of land cover. In this case, the four scenarios of initial soil moisture, based on real field measurements, were implemented for calculations, because the soil moisture is very variable in real space and time. This variability was documented thanks to presented results. For optimal calculations in 
Erosion-3D model, it would be better to use more real field measured data, mainly for bulk density.

\section{ACKNOWLEDGEMENTS}

This article was supported by the Slovak Research and Development Agency under the contract No. APVV-15-0425, No. APVV-15-0497, VEGA Agency 1/0710/15, and by the European Commission's Seventh Framework Project RECARE, Contract No. 603498. The authors thank the agencies for their research support.

\section{REFERENCES}

[1] ABBOTT, M.B., J.C. BATHURST, J.A. CUNGE, P.E. O'CONNELL, J. RASMUSSEN. An introduction to the European Hydrological System — Systeme Hydrologique Europeen, "SHE", 1: History and philosophy of a physically-based, distributed modelling system, Journal of Hydrology. 1986. vol. 87, no. 1, 1986. p. 4559, ISSN 0022-1694.

[2] ANTAL, J., STREĎANSKÝ, J., STREĎANSKÁ, A., TÁTOŠOVÁ, L., LACKÓOVÁ, L. Ochrana a zúrodňovanie pôdy. Nitra: SPU. 2013. s. 206. ISBN: 9788055212050 .

[3] BHUYAN, S.J., KALITA, P.K., JANSSEN, K.A., BARNES, P.L. Soil loss predictions with three erosion simulation models. Environmental Modelling and Software. 2002. vol. 17, p. 137-146.

[4] KENDERESSY, P., Soil loss assessment in an agricultural landscape and its utilization in landscape planning. In: Ekológia. 2012. roč. 31, č. 3, s. 309-321.

[5] MICHAEL A., SCHMIDT J., SCHMIDT W. A.: Parameter Catalog Application (2D). Freiberg: Technische Universität Bergakademie. 1996. s. 169.

[6] NEARING, M.A., JETTEN, V., BAFFAUT, C., CERDAN, O., COUTURIER, A., HERNANEZ, M., BISSONNAIS, Y.L., NICHOLS, M.H., NUNES, J.P., RENSCHLER, C.S., SOUCHERE, V., VAN OOST, K. Modeling response of soil erosion and runoff to changes in precipitation and cover. Catena. vol. 61, p. 131-154.

[7] SCHINDEWOLF, M. SCHMIDT, J. Parameterization of the EROSION 2D/3D soil erosion model using a small-scale rainfall simulator and upstream runoff simulation. 2012. In: Catena. vol. 91, p. 47-55.

[8] STANKOVIANSKY M. Historical evolution of permanent gullies in the Myjava Hill Land, Slovakia. 2003. In: Catena. vol. 51, no. 3-4, p. 223-239.

[9] VYSLOUŽILOVÁ, B. KLIMENT, Z.: Modelování erozních a sedimentačních procesů v malém povodí. In: GEOGRAFIE. 2012. roč. 117, č. 2, s. 22.

[10] WEIGERT, A., WENK, G., OLLESCH, G. FRITZ, H. Simulation of snowmelt erosion using the EROSION 3D model. In: Journal of Plant Nutrition and Soil Science. 2003. vol. 166 , no. 6 , p. 128-130. ISSN: 1522-2624

[11] WHEATER, H.S., JAKEMAN, A.J., BEVEN, K.J. Progress and directions in rainfall-runoff modelling. In: Jakeman, A.J., Beck, M.B., McAleer, M.J. (Eds.), Modelling Change in Environmental Systems. John Wiley and Sons, Chichester, 1993. p. 101-132. 
[12] WERNER, M., 2004. Abschätzung des Oberflächenabflusses und der Wasserinfiltration auf landwirtschaftlich genutzten Flächen mit Hilfe des Modells EROSION 3D. GeoGnostic, Endbericht, Berlin.

[13] WERNER, M., 2006. Erosion-3D User manual, Ver. 3.1.1. GEOGNOSTICS. Berlin. p. 69. 